\title{
Subregional Development as the Basis of Economic Growth of Russia
}

\author{
Markova E.S.* \\ Lipetsk State Technical University \\ Lipetsk, Russia \\ e-mail: katerina_lesnih@mail.ru
}

\author{
Zageeva L.A. \\ Lipetsk State Technical University \\ Lipetsk, Russia \\ e-mail: liaza@yandex.ru
}

\begin{abstract}
The subject of the research is the tools of subregional development that are implemented in the Lipetsk region and ensuring its investment potential. The purpose of the work is to show the practical importance of sub-regional development for ensuring high rates of economic growth in the conditions of digitalization of the economy. The following tasks are solved: determined the factors of economic growth in conditions of digitalization of the economy; suggested a classification of the forms of subregional development; presented a system of subregional instruments implemented in the Lipetsk region; analyzed the functioning of special economic zones, clusters and private industrial parks. It is proposed to consider sub-regional systems as a set of objects of various activities of municipalities located on the territory of a particular subject of the Federation with the joint use of total territorial resources both to maximize the overall effect of these objects, and to achieve the private interests of each participant in the sub-regional system, ordered in a certain way. This approach makes it possible to create a multi-level system of regional development tools aimed at ensuring economic growth through the most optimal use of territorial resources. Building a three-level sub-regional system allows the region to expand the "funnel" of attracted investments, form "growth points", and improve the economic and social impact of projects implemented in a particular territory.
\end{abstract}

Keywords - economic growth, growth factors, region, subregional development, clusters, special economic zones, private industrial parks.

\section{INTRODUCTION}

Economic development, prosperity and well-being of any country's economy are linked to long-term economic growth, so achieving high and sustainable growth rates has always been one of the key goals of economic policy. Regardless of the scale and path of development, all territorial entities in the economic sense are dynamically developing socio-economic systems. According to the principle of integration, these systems can be international, macro-regional and sub-regional.

According to the authors, the sub-regional level is determined by economic relations and interactions within a single subject of the Federation. Sub-regional integration is the most expeditious in this regard, as it is determined by the actions of management bodies and economic entities located in the territory where it is possible to effectively ensure coordination and balance of interests of all participants in the process.
If the efforts of the subregion are combined, it is possible to ensure complementarity and synergy, which significantly increases the effectiveness and effectiveness of policy measures. In addition, the sustainable and inclusive growth of the subregion has important cross-border components that affect the entire economy of the country, which is especially important during the period of its transformation.

\section{LITERATURE REVIEW}

Economic development - the basis for the implementation of projects to improve the standard of living of the population, an essential characteristic of the existence of enterprises, that is, increasing socio-economic indicators of the country, which is reflected by the increase of production volume of gross national product, that is, a realization of the economic growth of the country.

In accordance with the definition of S. Kuznets, economic growth is understood as "a long-term increase in the ability to meet all possible needs of the population in the products of economic activity" [1, p. 306]. This concept has led to the emergence of such a definition as" inclusive / inclusive "growth, which is"... economic growth, in which opportunities are created for all segments of the population and material and non-material benefits are distributed fairly in society to improve its well-being" [2].

According to the authors, the key distinguishing feature of the concept of inclusive growth is the focus on two aspects: results and opportunities. Inclusive growth refers both to the process itself and to its end results, meaning that people must both contribute to economic growth and enjoy its benefits in a broad sense.

The condition for ensuring economic growth is a stable macroeconomic environment formed by the effective functioning of economic state institutions, a highly competitive business environment, a high level of aggregate demand, and the development of information and digital technologies.

From the point of view of achieving inclusive and sustainable growth the conditions for economic development are: general liquidation of poverty in all its forms; promotion of sustained, inclusive and sustainable economic growth, full and productive employment and decent work for all; creating a robust infrastructure, promoting inclusive and sustainable industrialization and fostering innovation; reducing inequality within and among countries; ensuring sustainable patterns of consumption and production. 


\section{ASSESSMENT METHODOLOGY}

One of the key macroeconomic indicators that characterize the country's economic growth is the gross domestic product (GDP) [3]. GDP is important for factor analysis, because it reflects the market value of all final goods and services, regardless of the ownership of the factors of production used for their production, produced on the territory of the state for a certain period of time [4]

The yearly dynamics of Russia's GDP in billion US dollars by year (1992-2019) according to the IMF is shown in fig. 1.

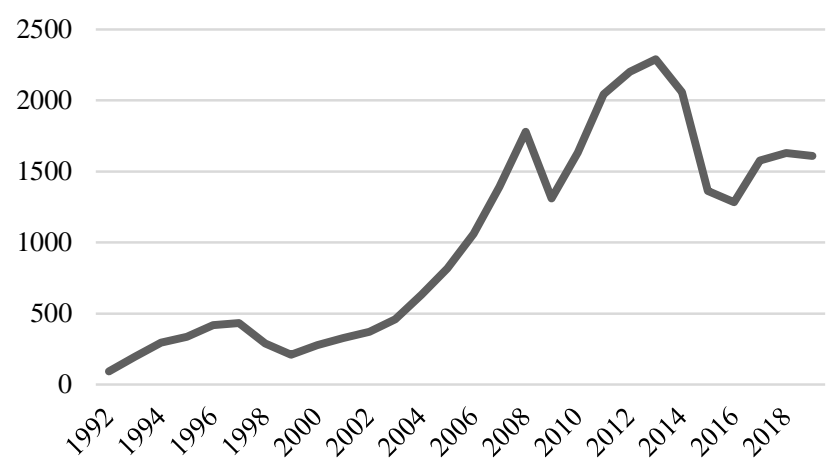

Fig. 1. Dynamics of Russia's GDP in $1992-2019$, billion

The dynamics reflect the need to develop new tools and methods for managing economic growth factors.

Economic theory identifies the following groups of economic growth factors [5]. The first group - supply factors - determines the importance of the availability of human and natural resources, fixed capital, and the level of technology development to ensure the economic growth of the territory. This group of factors is crucial for improving the quality of economic growth.

The second group of economic growth factors - demand factors-includes the level of prices, expenditures (investment, government, consumer), net exports and are mostly factors of extensive growth.

The third group - distribution factors - take into account the rationality and efficiency of resource usage in the processes of production and reproduction, that is, they form the intensive nature of economic growth.

The intensive type of economic growth determines dynamism both by expanding production and by optimizing the structural changes of the economic system. Thus, we can conclude that it is important to improve the structure of territorial development.

The current stage of development of structural entities is characterized by the emergence of new macro-regional forms with the participation of regions - subjects, as well as the development of sub-regional entities in the internal structure of the region. The sub-regional level is determined by economic relations and interactions within the same region. In other words, a sub-regional system is understood as an ordered set of objects of economic, investment, social and other activities of municipalities that are part of a particular subject of the Federation and characterized by the joint use of territorial resources to achieve the interests of all its participants [6].

Sub-regional development is carried out in various forms: economic, social and political systems can be distinguished by their orientation; sub-regional systems are divided into territorial-industrial complexes, clusters, and economic zones by their organizational form; state-municipal, private, or partner systems can be distinguished depending on the implementation of interests [7].

The emergence of each new sub-regional entity in the internal environment of the region should be justified by increasing the efficiency and sustainability of the territory's development, as well as increasing its competitiveness.

Let us consider the forms of sub-regional development on the example of the Lipetsk region. The gross regional product of the Lipetsk region remains positive. According to estimates, GRP grew by $2.2 \%$ in 2018 at comparable prices (by $2.3 \%$ in Russia) and exceeded the 0.5 trillion mark. RUB (Fig. 2).

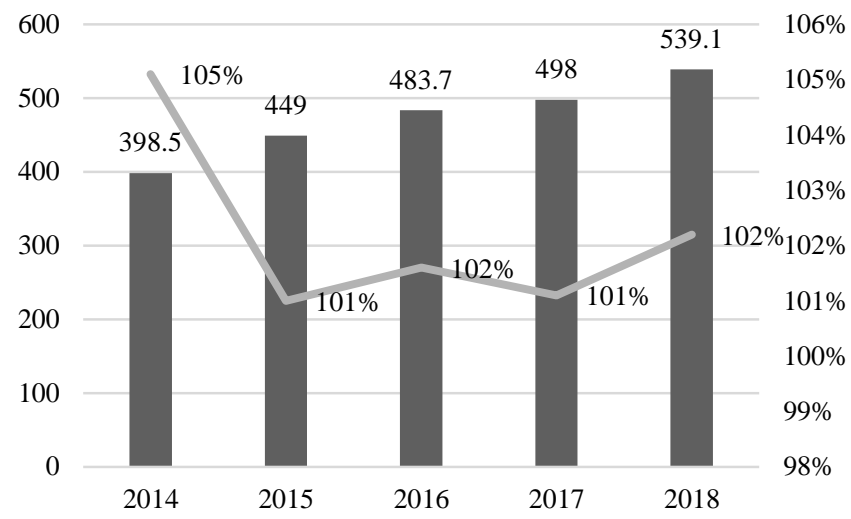

- gross regional product in current prices, billion rubles

- index of the physical volume of the gross regional product of the Lipetsk region, \%

Fig. 2. Dynamics of the Lipetsk region's GRP, 2014-2018

The share of industry in the GRP structure by type of economic activity is more than $43 \%$, including the share of manufacturing industries $-41 \%$. The share of agriculture, forestry, hunting, fishing and fish farming is $11 \%$, trade -9.7 $\%$, construction $-6.6 \%$.

In terms of gross regional product per capita, the Lipetsk region ranks 4th in the Central Federal district after Moscow, Moscow and Belgorod regions, and 23rd in the Russian Federation (2017). The gross regional product per capita (estimated) in 2018 was 469.8 thousand rubles $(102.7 \%$ by 2017 in comparable prices).

\section{ANALYSIS AND DISCUSSION}

The positive dynamics of the region's development is also due to the active development of sub-regional systems. Graphically, the structure of these systems located in the Lipetsk region is shown in fig. 3. 


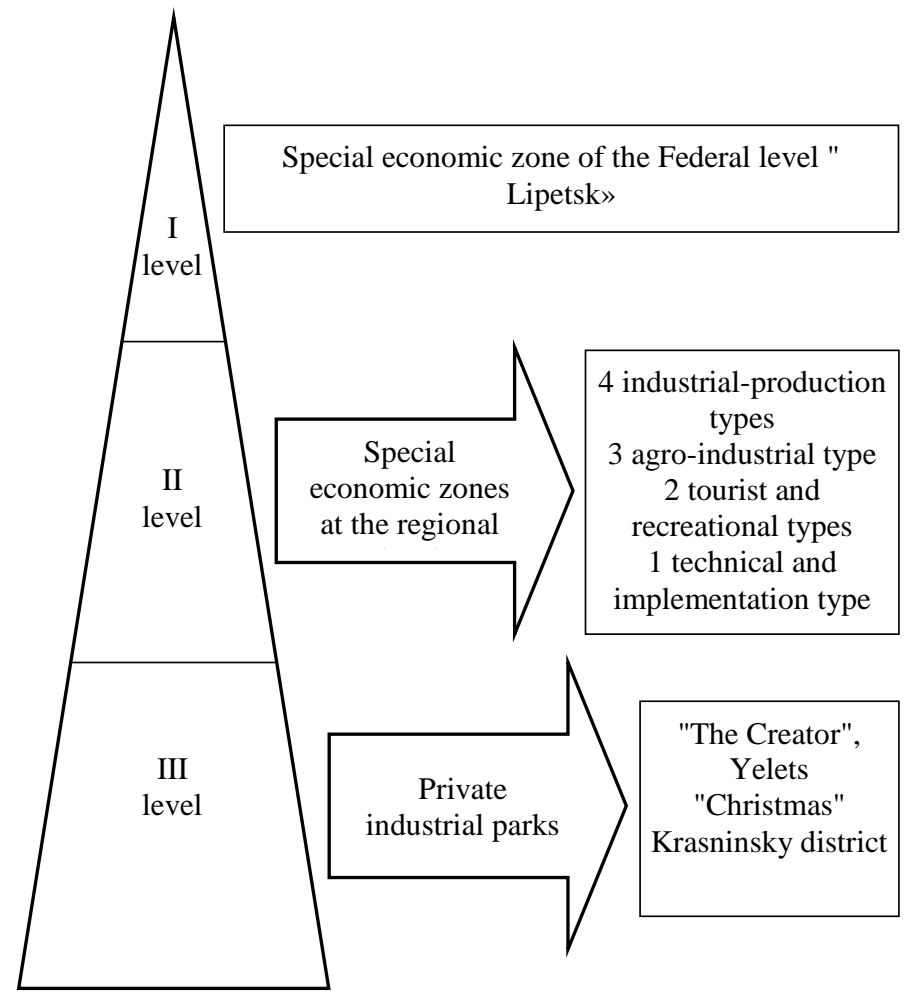

Fig. 3. Structure of sub-regional systems located in the Lipetsk region, 2019

The special economic zone of industrial production type (SEZ PPT) "Lipetsk" is a large - scale project that is part of a national initiative to create new points of economic growth and stimulate priority industries. The Lipetsk SEZ is a largescale, well-thought-out investment support system. Unique business conditions in the territory of the Lipetsk SEZ allow investors to achieve a $30 \%$ reduction in costs [8].

Dynamic infrastructure development of the industrial site, constructive interaction with residents, implementation of new practices and best investment development competencies determine the leading positions of the Lipetsk SEZ in Russia and Europe, and form innovative approaches to regional and industry development [9]. According to the rating of special economic zones in 2019, conducted by fDi Intelligence (a division of Financial Times Ltd), specializing in foreign direct investment, SEZ "Lipetsk" has the greatest number of special awards and is awarded in five nominations: "For the introduction of technologies, expansion projects, and For infrastructure development", "For new investments and reduction of administrative burden".

For the first 9 months of 2019, three companies with an investment volume of 2.9 billion rubles received the resident status: KVS Seed plant LLC (Germany), seed production and packaging; Syngenta Production LLC (Switzerland), plant protection products; Phoenix LLC (Russia), production of equipment for eco-friendly disposal of biological waste. To date, 62 residents have been registered with the volume of declared investments of 196 billion rubles, and 4.4 thousand jobs have been created [10]. Of these, 24 have already reached operational capacity, and more than 10 are in the active stage of design and construction.
Special economic zones of the regional level (SEZ RU) are created within the framework of the law of the Lipetsk region of August 18, 2006 No. 316-03 "On special economic zones of the regional level". In total, there are 10 Lipetsk region special economic zones of regional level (4 - industrial type (PPT), 3 - agricultural type (APT), 2 - tourism and recreation (TRT), $1-$ technology and innovation (TVT)).

The main characteristics of SEZ RU are presented in table 1 .

The dynamics of economic indicators in recent years shows that clusters are an effective form of sub-regional development, as a model for the development of industrial ecosystems [11]. The creation of a favourable tax and administrative environment, as well as the development of logistics infrastructure, is facilitated by the situation when an anchor investor appears and satellite companies gather around it. At the same time, enterprises are provided with qualified personnel. The example of such an ecosystem is the innovative territorial clusters created in the Lipetsk region:

- "Valley of mechanical engineering»;

- cluster of machine-tool construction and machine-tool industry "Lipetsk"»

- cluster of white equipment;

- cluster of composite materials and products made of them.

Clusters make it possible to understand the shortcomings of a particular enterprise's production. This allows the business to invest in the development of production on a point-by-point basis. In addition, high-tech jobs are created in clusters, where the competence centre is formed.

The mechanism for creating clusters can be divided into three stages. The first includes analysis of cooperation chains and identification of needs for new types of products. The second stage is pre-investment. This includes developing documentation, selecting sites, and searching for the best technologies and investors. The third stage is investment. It includes supporting investors in a single window mode, providing tax or other support measures, and searching for partners and potential product consumers [12].

Using this mechanism, 43 clusters were created in Russia. They combined more than 600 companies.

\section{CONCLUSION}

Economic development is more progressive when economic growth is adapted to sub-regional conditions, taking into account the socio-political situation, historical heritage, cultural traditions, geographical location, etc. In addition, reforms and policy measures produce the best results if they are supported by the population, while there is no single universal policy model that would provide the optimal solution in all cases. This should be taken into account when developing a policy framework for inclusive and sustainable growth in the subregion. 
TABLE I. MAIN CHARACTERISTICS OF SEZ RU LOCATED ON THE TERRITORY OF THE LIPETSK REGION

\begin{tabular}{|c|c|c|c|c|}
\hline $\begin{array}{c}\text { Name of SEZ } \\
\text { RU }\end{array}$ & Type & $\begin{array}{c}\text { Volume of declared } \\
\text { investments, mln. RUB. }\end{array}$ & $\begin{array}{c}\text { Number of } \\
\text { employees, people }\end{array}$ & Proposed for placement of the industry \\
\hline 1 & 2 & 3 & 4 & 5 \\
\hline Terbuny & PPT & 8570,6 & 1203 & $\begin{array}{l}\text { food industry; } \\
\text { processing industry; } \\
\text { construction industry; } \\
\text { chemical industry. }\end{array}$ \\
\hline Chaplyginskaya & PPT & 24860 & 1312 & $\begin{array}{l}\text { metallurgical industry; } \\
\text { light industry; } \\
\text { engineering industry; } \\
\text { chemical industry; } \\
\text { refining industry; } \\
\text { roadside complex that includes a public and business center, hotel, cafe, } \\
\text { gas station, Parking, shopping complex and recreation area }\end{array}$ \\
\hline Dankov & PPT & 22802.4 & 885 & $\begin{array}{l}\text { machine building and Metalworking industry; } \\
\text { construction industry; } \\
\text { small and medium-sized businesses; } \\
\text { processing industry; } \\
\text { chemical industry; } \\
\text { administrative and business center with hotel }\end{array}$ \\
\hline Eletsprom & PPT & - & - & $\begin{array}{l}\text { light industry; } \\
\text { food industry; } \\
\text { engineering industry; } \\
\text { utility and warehouse companies; } \\
\text { transport companies; } \\
\text { objects of social and consumer services }\end{array}$ \\
\hline Astapovo & APT & - & - & $\begin{array}{l}\text { food and processing industry; } \\
\text { construction industry; } \\
\text { objects of social and consumer services; } \\
\text { recycling and disposal of waste }\end{array}$ \\
\hline Izmalkovo & APT & 1795.8 & 219 & \multirow{2}{*}{$\begin{array}{l}\text { agricultural; } \\
\text { promyshlennaya; } \\
\text { processing }\end{array}$} \\
\hline Stable & APT & 7742.3 & 532 & \\
\hline $\begin{array}{c}\text { Lipetsk- } \\
\text { Technoplus }\end{array}$ & TVT & 259.75 & 288 & $\begin{array}{l}\text { Plot } 1: \\
\text { construction of the innovation center (building with research, laboratory, } \\
\text { administrative and household premises, underground Parking for } 50 \text { cars } \\
\text { with auxiliary premises); } \\
\text { office space with a cafe-restaurant with } 50 \text { seats, exhibition and } \\
\text { conference rooms, a hotel and auxiliary facilities. } \\
\text { Plot 2: } \\
\text { Innovative developments in the field of: } \\
\text { engineerings; } \\
\text { medicines; } \\
\text { energies; } \\
\text { metallurgies. }\end{array}$ \\
\hline Yelets & TRT & 1319 & 400 & \multirow{2}{*}{$\begin{array}{l}\text { tourist; } \\
\text { sanative; } \\
\text { recreational }\end{array}$} \\
\hline Zadonschina & TRT & 8605 & 340 & \\
\hline
\end{tabular}

The conducted research allows concluding that one of the necessary directions of economic reform is to strengthen the focus on the development of human capital and physical infrastructure as fundamental components of the growth strategy aimed at diversification and inclusiveness. In turn, education and infrastructure largely determine the ability of the economy to engage in innovation and modernization, while ensuring that such efforts are inclusive. The more diverse, complex and comprehensive the knowledge base - the more real opportunities open up for the economy. The knowledge base determines the possible path of economic development, products, clusters and industries that it can develop, as well as its capabilities in terms of innovation, development of new industries and creation of new jobs.

The combination of the necessary human capital, physical infrastructure and favorable business environment is one of the conditions necessary for the prosperity of entrepreneurship and the emergence of cyclical processes of demand and supply development that can contribute to economic diversification and stimulate sustained economic growth in the subregion.

The efforts to support such development will be more successful if they rely on local initiatives and help local entrepreneurs open up new business opportunities, using the potential of clusters, technology parks and special economic zones. Therefore, it is worth focusing on support institutions that will respond to existing demand and give an immediate effect.

The next proposal that promotes economic growth may be the implementation of business support programs based on the allocation of micro-loans for small amounts. It can cover all sectors of the economy and activities in general, and thus also contribute to the diversification of the economy. Microfinance on preferential terms can be a suitable tool for supporting young entrepreneurs, women entrepreneurs, and vulnerable groups, so it will contribute to the inclusiveness of such development efforts. In addition to funding, these support 
programs should provide a wide range of information and advisory services for potential entrepreneurs.

\section{References}

[1] World economic thought, vol. 5, kn. 1, Lectures of Nobel laureates, Rev. ed. Moscow: Thought, 2004, 767 p.

[2] Opportunities for All: a Framework for Policy Action on Inclusive Growth. Paris: OECD Publ. Retrieved from: https://doi.org/10.1787/ 9789264301665-en.

[3] R.L. Ranieri, R.A. Ramos, "Inclusive Growth: Building a Concept", International Policy Centre for Inclusive Growth, Working Paper, no. 104, March 2019.

[4] World Economic Forum, The Inclusive Growth and Development Report 2017.

[5] N.A. Serebryakova, I.V. Avdeev, "The content of structural transformations of the region's economy, adapt to the requirements of digitalization", Proc. of the Voronezh State Univer. of Engineer. Technol., vol. 80, no. 4, pp. 408-412, 2018. Retrieved from: https://doi.org/10.20914/2310-1202-2018-4-408-412

[6] O.G. Charykova, E.S. Markova, Regional clustering in the Digital Economy, Regional Economy, vol. 15, no. 2, pp. 409-419, 2019.

[7] E.S. Markova, L.A. Zageeva, "Marketing in the conditions of transition economy on the digital rails", Modern econ.: probl. and solutions, vol. 11, no. 95, pp. 57-65, 2017.
[8] Y.P. Anisimov, Y.V. Zhuravlev, I.V. Kuksova, E.I. Balabanova, A.Y. Zhilnikov, T.V. Elagina, "Spatial analysis of the development of innovative potential of enterprise", Proc. of the Voronezh State Univer. of Engineer. Technol., vol. 81, no. 1, pp. 391-396, 2019. Retrieved from: https://doi.org/10.20914/2310-1202-2019-1-391-396

[9] "The digital economy of russia in the new technological order", Innovat. Econ. and law, vol. 1, no. 10, pp. 28-30, 2018.

[10] E.V. Balatsky, N.M. Pliskevich, "Economic growth in extractive institutions: the Soviet paradox and modern events", World of Russia: sociology, Ethnology, vol. 26, no. 4, pp. 97-117, 2017.

[11] C.M. Drobyshevsky, G.I. Idrissov, A.S. Kaukin, P.N. Pavlov, S.G. Sinelnikov Murylev, "Decomposition of growth rates of the Russian economy in 2007-2017 and forecast for 2018-2020", Quest. of Econ., no. 9, pp. 5-31, 2018.

[12] E.S. Markova, "Analysis of the cluster-network model for organizing the region's space in the conditions of digitalization of the economy innovative entrepreneurship: the experience of regions", pp. 45-50, 2018 [Materials of the Int. sci. and pract. Conf.].

[13] E.S. Markova, "The importance of clustering in the organization of the socio-economic space of the region in the conditions of digitalization of the economy agro-industrial complex of the eaeu countries: economy and management", pp. 179-181, 2018 [XVII Int. sci. and pract. Conf.].

[14] A.Yu. Bricheev, L.A. Zageeva, Modern stage of cluster development in russiactual problems and prospects of economic development: russian and foreign experience. Moscow: Publ. Optimus limited liability Company. ISSN: 2541-8572 